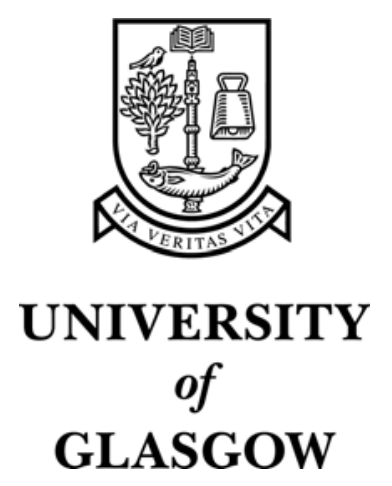

Hall, A. (2005) Getting shot of elves: healing, witchcraft and fairies in the Scottish witchcraft trials. Folklore 116(1):pp. 19-36.

http://eprints.gla.ac.uk/3081/ 


\title{
Getting Shot of Elves: Healing, Witchcraft and Fairies in the Scottish Witchcraft Trials
}

\author{
Alaric Hall \\ 'Getting Shot of Elves: Healing, Witchcraft and Fairies in the Scottish Witchcraft Trials', \\ Folklore, 116 (2005), 19-36.
}

\begin{abstract}
This paper re-examines the evidence of the Scottish witchcraft trials for beliefs associated by scholars with "elf-shot." Some supposed evidence for elf-shot is dismissed, but other material illuminates the interplay between illness, healing and fairy-lore in early modern Scotland, and the relationship of these beliefs to witchcraft itself.
\end{abstract}

\section{Introduction}

The study of popular belief in early modern Scotland is in good health. The unusually numerous attestations of Scottish fairy-belief in the witchcraft trials, on which this paper focuses, have recently received close attention (Purkiss 2000, especially 85- 157; 2001; Wilby 2000; Henderson and Cowan 2001; cf. Maxwell-Stuart 2001; Hutton 2002, especially 27-32). Open-access web resources now include the Dictionary of the Older Scottish Tongue (hereafter DOST), the Helsinki Corpus of Older Scots and the Survey of Scottish Witchcraft (hereafter SSW), conceived as "an extensive database of all people known to have been accused of witchcraft in Scotland between 1563 and 1736," published in January 2003. [1] These resources facilitate and invite the critical reassessment of our inherited assumptions about the subject: accordingly, I consider here our earliest Scottish evidence for one aspect of this subject, elf-shot.

Scholarly usage of the term "elf-shot" varies. The New Shorter Oxford English Dictionary (sub Elf n.') offers "a disease, esp. of livestock, attributed to the agency of elves," adding that in Scots elf-shot could be synonymous with elf-arrow, "a flint arrowhead (regarded as an elves" weapon)." Perhaps in consequence, "elf-shot" is sometimes understood to mean disease caused specifically by elves using projectiles (for example Jolly 1996, 134). On the other hand, it is sometimes used to denote witchcraft effected by means of projectiles but not involving elves or fairies (for example Bonser 1963, 159-60), or even ailments with no implication of elves, witchcraft or projectiles, as by Cockayne in his translations of the Old English medical texts, who used it in the sense "dangerously distended by greedy devouring of green food" $(1864-6$, vol 2, 291, 401). Finally, the SSW used "elfshot" to mean "prehistoric arrowhead thought to be used by fairies/witches to cause harm, [which] could also be used as a protective amulet." [2] Unsurprisingly, then, scholarship touching on elf-shot is rife with confusion. Thus the $S S W$ routinely identifies "elfshot" according to definitions other than its own, and misses instances which fit it.

In this article, I avoid a specific definition of "elf-shot" as a scholarly term; what I 
am studying is the association between fairies, illness, projectiles and their necessary concomitant, healing, in the Scottish witchcraft trials. Projectiles themselves are a complex issue. The concept of harm being supernaturally inflicted by projectileswhether physical or metaphysical, or even metaphorical - is widespread (Honko 1959). As to how such projectiles might have been envisaged in early modern Soctland, I wish simply to assess the evidence of the sources. Having limited my sources primarily to Scottish witchcraft trials, I hope that comparison of my findings with later Scottish evidence, English evidence, or with folklore from elsewhere in Europe, will not be compromised by circular argumentation. However, besides reassessing the evidence regarding "elf-shot," I aim to improve our understanding of the constructions of harm, healing and witchcraft in early modern Scotland by suggesting plausible models for the developments and functions of the traditions attested. Ronald Hutton in particular has offered some suggestions for interpreting the relationship between fairies and Scottish witchcraft beliefs (2002, especially 27-32); my own analysis offers a new point of entry into the material, allowing us to begin to test some of his ideas and to propose more specific models which future analyses may substantiate, complement or modify.

Studies of Scottish popular belief in the trials have hitherto emphasised narratives. Henderson and Cowan (2001, especially 35-105), and Purkiss (2001; 2000, especially 85-157), have argued that fairy-narratives were involved in demarcating boundaries and threats in Scottish society, and in providing modes of discourse for comprehending their transgression. Here, however, I concentrate more on the evidence of language. This encourages linguistic precision in analysing the trials; moreover, early Scottish narratives also contain few details of fairies' roles in the aetiology of illnesses (though see Henderson and Cowan 2001, 74-105), but the semantics of the words used in these narratives can reveal new information. It is worth noting in this context that scholars of Scottish fairy-lore have not hitherto distinguished between the words elf and fary in their sources - the SSW, for example, took "the terms fairy and elf to be interchangeable" (cf. Henderson and Cowan 2001, 17). [3] Most use modern English "fairy" of both. This is certainly defensible: fary is a French loan in English which over time has tended to displace the etymologically English elf (OED, sub Elf, Fairy), and it seems likely that Older Scots exhibits this process. Even so, the synonymy of elf and fary should be regarded as a working assumption which requires fuller examination. Trow in the Northern Isles could also be considered (cf. DOST, sub Troll). Fortunately, my sources use fary only once, and never trow, so I maintain the scholarly tradition with minimal misgivings. Presumably the dominance of elf- in compound words denoting ailments is because these, or their models, predate the use of fary in Scots; but social variation may have been involved as well, presumably exhibiting the usual English pattern whereby French loans spread from higher to lower social registers of speech. It is also worth stressing that neither elf nor fary is etymologically Celtic, since there is a long-standing scholarly tradition of associating fairy-beliefs in Western Europe with "Celtic" culture, which belies the possible range of sources for such beliefs in Scotland. In particular, Maxwell-Stuart recently opted to use sithean as his standard term, and seems to have assumed that fairy-beliefs were distinctively associated with Highland culture (2001, 10 17). But this Gaelic term never occurs in the material studied here; where we do have relevant trials from Gaelic-speaking areas, they are recorded in English.

My sources are primarily those trials in the SSW database table 
"Elf_FairyElements" and those cited in DOST (sub Elf, Fary, Schot), which have been published; my exclusion of unprinted evidence has led to the omission of only one case, exhibiting "elfshot" in the SSW (Elspeth Culsetter, Orkney, 1644). The Helsinki Corpus of Older Scots was searched, but contributed no extra material. Other relevant material was added when encountered. Trials are referred to by the names of the accused, the county in which they lived, and the end-date of their trial, in the forms used by the SSW, to facilitate comparison with the database. Paraphrases suggesting the likely resolution of syntactic problems or ambiguities and glosses added to source texts are my own. The study is divided into three parts, on linguistic grounds. I begin by dismissing cases in which elf-shot has been perceived only by the misunderstanding (or at best dubious interpretation) of the Scots words schot and schute. Next, I study the compound elf-shot itself, along with other words for ailments in the trials which include elf or fary. Finally, I analyse trials not already included which mention the term elf-arrow-heid or a variant of this. Although this division is linguistically-motivated, the different kinds of elfcompounds tend also to be associated with different kinds of narrative. The terms elfschot, fareis schot, elfgrippit and elf-shooting occur in narratives about the healing of ailments probably thought to have been caused by fairies. By contrast, all but one of the trials mentioning elf-arrow-heidis concern their use by human witches in maleficium. The significance of this distribution is discussed at the end.

\section{Non-evidence}

The phrase to schute to dede "to die suddenly" has often been taken to imply "a sudden attack of illness or death as a result of a fairy dart" (Henderson and Cowan 2001, 77). Thus Smith, editing the records of the trial of Jeane Craig (Haddington, 1649), explained the phrase schot to dead with the note "Fell ill suddenly and died; 'shot' = a sudden attack of illness; 'shot-a-dead' = death from a fairy dart" (Smith 1974, vol 3, 813 n. 4). DOST subsequently cited this passage for schute in the sense "The superstition that sudden illness, injury or death might be caused by flint arrow heads shot by fairies, a power also claimed and 'practised' by witches" (sub Schute $\S 25)$. The text itself, however, suggests otherwise:

Lykas airly in ane uther morneing, schortlie thaireftir, the said James Smyth, having rancounterit with ane servand man of his leiding furth sax of the said James his horse, saluttit him with thir wiked wordis: "Quhat devill does thou man, soe sone up at morne," and croseing his way the said Jeane be hir sorcerie and witchcraft, laid upone thrie of the saidis horssis [that] thay presentlie schot to dead, and uther thrie horse, with the man servand himselff, schortlie thaireftir deceissit be hir sorcerie and witchcraft sua laid upone thame.

[Likewise, early on another morning shortly after that, (regarding) the aforementioned James Smith. Having encountered a serving man of James's leading forth six of the aforementioned James's horses, (Jeane) greeted him with these wicked words: "What the devil are you doing, man, up so soon in the morning?" And crossing his path, the said Jeane - by her sorcery and witchcraft-afflicted three of the aforementioned horses so that they immediately schot to dede; and the other three horses, along with the serving man himself, died soon thereafter, by the witchcraft and sorcery with which she thus afflicted them.] (Smith 1974, vol 3, 813).

Schute is used here in its common intransitive sense "to move suddenly, rapidly or 
forcefully" (DOST, sub Schute $\S \mathrm{I})$; dead is the noun meaning "death" (DOST, sub Dede $\S 3)$. As an intransitive verb, it can hardly be construed to denote the shooting of the horses, whether by "sorcerie and witchcraft" or otherwise: the phrase schot to dede effectively means, as DOST noted elsewhere "to die suddenly" (sub Schute, §7). This suddenness may, of course, have encouraged a diagnosis of witchcraft, but that is a different matter. As schute to dede occurs quite often in the witchcraft trials, its misinterpretation has produced the impression that the concept of "elf-shot" or "fairy darts" was widespread. [4] But the phrase affords no such evidence.

The noun schot has also caused confusion, probably because in Modern English it almost invariably denotes projectiles or their releasing. But schot occurs several times in Older Scots meaning "A sudden sharp pain; a spasm of pain; a shooting pain" (DOST, $s u b$ Schot §2). This meaning is also attested for its cognates. The Middle English Dictionary offers the meaning "a muscular spasm of the neck or back; a spasmodic pain in the side, stitch" (sub Shot $\S 4 \mathrm{e}, \mathrm{cf} . \S 4 \mathrm{~d})$, a sense also attested in modern English (OED, sub Shot, n. §I.1.b), and in other medieval Germanic languages (for example Söderwall 1884-1918, sub Skut §3; Lexer 1869-76, sub Geschôz, Schuz). However, Scots schot has sometimes been taken to imply "a shot from an elf or fairy arrow, and used by witches" (DOST, sub Schot $§ 10)$. DOST offers two citations for this meaning, both cases accepted by the SSW to exhibit "elf-shot." Neither stands up to scrutiny. The first is from the trial of one Meriorie Mutche (Aberdeen, 1597). Meriorie was alleged, in a well-poised narrative turning nicely on the polysemy of schot, to have had a dispute with one William Cowpar over space in a mill. William gave Meriorie "ane schott with his hand," schot evidently meaning "a thrust" here. "Thow said," Meriorie's indictment goes on, "... thow suld put ane schot in his syde, within xlviij houris, that suld do him gryter harme nor that schot did the" ("you said you would put a schot in his side, with 48 hours, that would do him greater harm than his schot did to you;" Stuart 1841-52, vol. 1, 131). Meriorie returns William's blow by drawing on schot's alternative meaning "a sudden sharp pain," her revenge qualitatively different from the provocation, but verbally matched to it. But there is no reason to infer that Meriorie's schot connotes the involvement of fairies or projectiles. In the same witchcraft panic, Jonat Leisk (Aberdeen, 1597) was accused of causing symptoms identical to those which Meriorie caused William, including "ane schot" in the victim's side, but her technique was specified: Jonat allegedly "maid his picture in walx ... and pat the same on ane spitt nichtly" ("made his image in wax ... and put it on a spit at night"; Stuart 1841-52, vol. 1, 137). There can be no plausible inference of elf-shot here in any sense. Ten years later, Bartie Patersoun (Edinburgh, 1607) was accused of using this charm on cattle:

\section{CHARME}

thé for arrow-schot, for dor-schot, for wondo-schot, for ey-schot, for tung-schote, for leverschote, for lung-schote, for hert-schot, all the maist, in the name of the Father, the Sone and Haly Gaist . A MEN [I charm you for arrow-schot, for door-schot, for window-schot, for eyeschot, for tongue-schot, for liver-schot, for lung-schot, for heart-schot, all the most, in the name of the Father, the Son and the Holy Ghost. Amen.] (Pitcairn 1833, vol. 2, 536).

Elf here is conspicuous by its absence: to take the text as evidence for "protective charms against elf-shot" (Henderson and Cowan 2001, 78) is an unacceptable inference (cf. Bonser 1963, 158-9). 


\section{Elf-schot, noun and participle, and similar compounds}

We may now consider the noun elf-schot itself. Perhaps surprisingly considering its prominence in secondary literature, I have found only one instance of a noun elf-schot in the trials, only one other in Older Scots, and no earlier examples in English. Although the noun and the past participle elf-schot are identical in form, their grammatical functions are different, and they must be considered separately. It is tempting, for clarity, to follow the $O E D$ (sub Elf-shoot) and use an infinitive citation form elf-schute for the past participle; but elf-schot no more implies **elf-schute than worm-eaten implies **wormeat. Both attestations of the noun elf-schot are worth including here. The earlier is from a poem in Magdalene College, Cambridge, Pepys Library MS 2553 (the Maitland Folio Manuscript) there called "the cursing of S Iohine rowlis," the manuscript being written between 1570 and 1586 (Craigie 1919-27, vol. 2, 1-6). The text implies in line 8 that one "paip alexander" holds the papacy, presumably Alexander VI, pope from 1492-1503. However, it also appears in National Library of Scotland, MS. Advocates 1.1.6 (the Bannatyne Manuscript), written in 1568 (Fox and Ringler 1980, xv-xvi); here the line concerning elf-schot is absent, so it may not be original. Concluding a fifty-nine-line list of afflictions, Rowll wishes upon the thieves of his poultry

\footnotetext{
The mowlis and in pair sleip pe mare The canker also and the caterss And never to be but schot of blude Or elf schot pus to conclude and mony vther maletais

[Chilblains and in their sleep, the mare; / the sore also and the rheums; / and never to be without schot of blude / or elf-schot, thus to conclude, / and many other maladies.] (Craigie 1919-27, vol. 1, 163, lines 65-9).
}

This is one of the few Older Scots attestations of the reflex of Old English mcere, denoting supernatural female nocturnal assailants (surviving now only in nightmare; DOST, sub Mare, n.'; cf. MED, sub Māre, n. (2); OED, sub Mare, n. ), which is found in association with elf and its relatives not only here, but in Old and Middle English and Middle High German (for example Cockayne 1864-6, vol. 2, 138-40; Horstmann 1887, 306-7; von Grienberger 1897): Rowll's literary curse evidently draws here, at whatever remove, on an old tradition. More importantly, elf schot is clearly a hyponym of maladye ("malady") - that is, its meaning must fall within the semantic range of maladye - so cannot denote a projectile. The juxtaposition with schot of blude is unfortunately less helpful, as the meaning of this is uncertain (DOST, sub Schot $\S 3 \mathrm{~b}$, suggests "discharge of blood," where, however, this text affords the only citation). Much the most likely interpretation of elf-schot, then, is the sense noted above, "A sudden sharp pain; a spasm of pain; a shooting pain."

The noun elf-schot otherwise occurs in the indictment of Agnes Sampsoune (Edinburgh, 1591), the most prominent of those accused in the infamous North Berwick witchcraft trials. References to supernatural beings in Agnes's trial are much influenced by demonological writings (see Normand and Roberts 2000, 207-10), but the second of the fifty-three indictments against her claims that, "Williame Blakeis sone sark being send to hir, scho be hir Wichcraft declarit, that the seiknes that he had was ane elf-schot" ("Williame Blake's son's shirt being sent to her, she declared, through her witchcraft, that the seiknes that he had was an elf-schot"; Pitcairn 1833, vol. 1, pt. 2, 231). Agnes's 
"Wichcraft" here lies not in causing an ailment, but in diagnosing it. Elf-schot is almost certainly a hyponym of sekenes, which seems to have denoted diseases and ailments, of the body and mind, or metaphorically concepts like infatuation or sinfulness, but only very rarely wounds (DOST, sub Sekenes; cf. MED, sub Sīknesse; OED, sub Sickness). Once more, then, the appropriate sense of -schot here is probably "a sudden sharp pain," rather than "a projectile."

What, then, is the significance of elf- in elf-schot? In English the first element of such a compound (the determiner) must modify the second element (the generic), whose meaning is basic to the compound: so elf-schot is a specific sort of schot. Of the possible semantic relationships between the elements of elf-schot, the likeliest is the common pattern whereby the generic results from the determiner (Marchand 1969, §§2.2.9-14, 2.3-15, especially $\S \S 2.2 .14 .3 .1-2$; Carr 1939, 321-39, especially 323-4): thus elf-schot is, etymologically, probably a schot caused by elvis. Although elf-schot does not occur earlier in English, similar Old and Middle English compounds, such as celfsogoða and elfcake, seem also to have denoted internal pains believed to have been caused by elves, so elf-schot would stand in a well-established tradition (Hall forthcoming; cf. MED, sub Elf, Elven; OED, sub Elf, n. ). However, in Older Scots, elf-schot could have been a bahuvrihi compound - that is, it may have developed a meaning different from that implied by its constituent elements, as in Cockayne's usage of elf-shot noted above. If so, it may no more have meant "a schot caused by elvis" than "bodice ripper," "a sexually explicit romantic (historical) novel," means "a ripper of bodices." However, this seems unlikely: elf-schot evidently denoted illnesses, and elvis and fareis were widely believed in early modern Scotland to be able to cause these (Henderson and Cowan 2001, 74-105), so the chances were that elf-schot would be used and understood literally. Moreover, there are positive indications that similar Scots compounds, considered next, did connote the actions of elvis.

The past participle elf-schot occurs twice, along with the curious compound elfshooting. In principle, this elf-schot again seems likely to be a hyponym, this time of the past participle of schute. Of the attested possibilities, the force of the determiner elf-here is almost certainly the usual one, suggesting the subject of the verb from which the generic is formed: ane elf schot a man $\rightarrow$ ane elf-schot man (see Marchand 1969, §2.23; Carr 1939, 340). Although the sense is attested in English (MED, sub Shēten §6b; OED, sub Shoot, $v$. §I.5, Shooting §3; Hall forthcoming), Older Scots schute does not seem to be attested to mean "cause pain" or the like (DOST, sub Schute), so in this case, elfschot is liable at least to have connoted shooting - though etymologically the compound might have denoted the experiencing of pain. The attestations themselves support this analysis. The earliest occurs in a transcript in the diary of Sir George Maxwell of Pollok of the trial-records for Joanet Scott (Paisley, 1650) and Jeane Scott (Paisley, 1650), held on consecutive days (and omitted from the SSW). The first of these brief attestations runs:

Article.-When kine wer elfe shote. ... [lacuna in manuscript]

Answer.-Confessed that shee had so graiped certaine kine, and that shee hearde that this would cuire the cow. For the elfes, shee heard that they wer the good neighboris.

[Article: When cattle were elf-schot. ...

Answer: Confessed that she had graiped certain cattle in that way, and that she heard that this 
would cure the cow. As for the elvis, she heard that they were the good neighbours.] (Fraser 1863, vol. 1, 352).

It appears that Joanet was asked about what she did when cattle were elf-schot; as with Agnes Sampsoune, the indictment seems to concern healing by proscribed means rather than contact with fairies, or causing harm. Joanet confessed in response that she had graiped the cattle; DOST defined the word with "to touch with the hands, handle; to examine by touching, feel"; "to lay hold of, grasp; to search for, or make a search in"; "To put out the hand in order to feel or to find something" (sub Grape). It is not clear whether Joanet's further comment on elvis reflects her own train of thought, provoked by the mention of elf-schot, or whether she made it because she was asked about elvis in an enquiry lost from the text. Either way, however, there is a strong implication that the term elf-schot brought elvis to mind for someone in the trial, suggesting that elf- was indeed understood to imply the actions of elvis.

For her part, Jeane was accused of "Elfe shooteing cured by three fingeris of different persons putt in the holl [hole]" (Fraser 1863, vol. 1, 358). "Elfe shooteing" is an odd usage: the determiner in compounds of noun+verbal noun should be the object of the verb (Carr 1939, 322; Marchand 1969, §2.10; cf. "deer-shooting”), but Jeane was surely not accused of shooting elvis. The compound should probably be understood as an infelicity reflecting the compressed legalistic language of the text in conjunction with the lack of a noun denoting elvis' causing of schottis, and influence from compounds of noun+deverbal noun in which the determiner reflects a subject, such as "headache" (cf. Marchand 1969, §2.11.1-4). "Elfe shooteing" is too odd to be a bahuvrihi compound and surely implies that elvis were understood as the cause of the shooting. Jeane's indictment is particularly interesting because it implies that "Elfe shooteing" caused a hole, suggesting that schute was understood along the lines of "to discharge a missile" (DOST, sub Schute §III) and that elf-schooting was understood to denote elvis' use of projectiles - whether physical, metaphysical or metaphorical - to cause an ailment. While this is not a certain inference, it strikes me as the most plausible. It is consistent with the remaining attestation of elf-schot in the Scottish witchcraft trials which I know, in the late and unprinted trial of Farquhar Ferguson (Arran, 1716, omitted from the SSW). Farquhar was charged with "curing by charms 'people that were Elf Shot' "' (Gilmore 1948, 110), and "admitted that he was frequently called upon to 'search for holes in people that were suspected to be shot' " (Henderson and Cowan 2001, 79).

Besides elf-schot, Older Scots also attests once to elf-grippit, in the trial of Bessie Dunlop (Ayr, 1576). Bessie's trial is well-known, as she gave a detailed account of her relationship with Thom Reid, a dead man in the service of the "Quene of Elfame" (see Purkiss 2000, 111-2 and 149-50; Henderson and Cowan 2001, 129-30; Maxwell-Stuart 2001). Bessie confessed that

quhen sundrie persounes cam to hir to seik help for thair beist, thair kow or yow, or for ane barne that was tane away with ane evill blast of wind, or elf-grippit, sche gait and sperit at Thom, Quhat mycht help thame?

[when various people came to her to seek help for their animal, their cow or ewe, or for a child that had been ravished by an evil blast of wind, or elf-grippit, she went and enquired of Thom "What might help them?"] (Pitcairn 1833, vol. 1, 53). 
Grip is defined in DOST with "to seize ... to clutch," and could be used of internal pains (sub Grip $§ 1$ b; cf. Gripe). Bessie listed the state of being elf-grippit alongside "ane evill blast of wind"; as the "blast" is associated with fairies elsewhere in the witchcraft trials and in other Scottish evidence, its collocation with elf-grippit suggests that here, as generally in her trial, fairy-lore was in her mind (Henderson and Cowan 2001, 77-9; cf. SSW, database table "Elf_FairyElements," under the field names "Fairy Blast," "Whirlwind"). Once again, medieval English parallels also exist, in the compounds elftaken and fairy-taken, taken being used in senses like grippit (MED, sub Elf, T ken $\S 2 \mathrm{~b}$, cf. elue-inome cited sub Blouen v. (1) §2c; OED, sub

ā Take, v. §I.7; Thomas 1973, 725). Elf-grippit, then, provides a close parallel for the participle elf-schot, and does not suggest causation by projectiles, consolidating my argument above that an elf-schot need not have involved a projectile. However, it seems likely that although the connotation could be a late development, by 1650 the past participle elf-schot was not only in use, but understood to connote projectiles.

Finally, elf-schot is also paralleled in the trial of Stein Maltman (apparently to be identified with Steven Malcome, Stirling, 1628), which mentions "fairies schott". [5] The semantic relationship between these words is unambiguous: the schot belongs to the fareis, and presumably was caused by them. Once more, the phrase offers no evidence for the use of projectiles. Stein's trial also introduces us to the term elf-arrowstone. Alongside elf-arrow, elf-arrow-heid and elf-stone, this term attached from at least the seventeenth century to neolithic flint arrow-heads, and the witchcraft trial records seem to demand a similar interpretation (DOST, sub Elf-arrow; OED sub Arrow §1c, Arrow-head $\S 1$ b). Stein was accused of attributing illness in people to the "fairye folk" on several occasions, and confessed that he gained his healing skills "of the fairye folk quhom he had sein in bodilie schapes in sindrie places" ("from the fairy folk, whom he had seen in bodily forms in various places"; F. 1893-1908, vol. 4,185). In his fullest confession to mention an elf-arrow-heid, he confessed that in healing one Jonet Chrystie,

he brocht in some south running water, seathed it in ane pan, and put one elff-arrow stone in the water because it wes ane remedie against the fairies schott, that he gave to the said Jonet Chrystie ane drink thereof, and immediatlie efter the said Jonet had drunk thereof the said Stein caused the hail servants to depairt out of the house for fear they should ressave skaith of her, and particularlie he had Elspet Steinsoune their servand, being lying beyond the said Jonet Chrystie in ane Longsettle, cum furth and leave her, for, said he, gif any evill cum on thee I will never get mends for thee.

[he brought in some south-running water, boiled it in a pan, and put an elf-arrow-stone in the water because it was a remedy against the fairies' schott; he gave the aforementioned Jonet Chrystie a drink thereof. And immediately after the aforementioned Jonet had drunk from it, the aforementioned Stein had the hale servants depart from the house for fear that they should receive harm of her [Jonet]; and in particular he had their servant Elspet Steinsoune, who was lying beyond the aforementioned Jonet Chrystie in a longsettle [a kind of long seat], come forth and leave her [Jonet], because, he said, "If any harm comes to you, I will never find a remedy for you.’] (F. 1893-1908, vol. 4, 187).

Although Stein may have intended the water which he had Jonet drink to force the illness out from her, such that it might harm others in the house, we do not have to suppose that this illness was envisaged as an embedded projectile. Nor do Stein's other 
two confessions of healing with an elf-arrow-heid (once by washing, once by rubbing his client with it) suggest such an interpretation. Elf-arrow-heid could have been associated, both etymologically and synchronically, with elf because the objects which it denoted were obviously manufactured items but had no apparent source in the human community, rather than because they were viewed primarily as the means by which elvis inflicted illnesses. Stein's use of the elf-arrow-heid in curing illnesses caused by faries presumably involved an element of curing like with like - a fairy object used against a fairy illness - but this need not imply that the ailment was thought to have been caused by an elf-arrow-heid itself.

So far, then, there is good evidence, in six trials from 1576 to 1716, for beliefs that fairies caused ailments, especially internal pains, both in humans and livestock. As I discuss below, this is a small number, but the evidence is reasonably coherent. There is evidence that by 1650 , elvis were thought to inflict illness using projectiles, but this is by no means a necessary assumption for earlier data. The means by which a schot or similar pain was identified as an elf-schot are little-attested, but apparently varied: Agnes Sampsoune seems to have examined her client's shirt; Farquhar Ferguson searched his clients' bodies for holes. Stein Maltman and Bessie Dunlop confessed to gaining powers of healing directly from fareis, but in no case did a healer use such contact for maleficium. These cases provide evidence for Hutton's basic paradigm of otherworldly beings outside the human community causing certain kinds of illness, and members of the community healing them $(2002,20,27-32)$, in Lowland Scotland, alongside beliefs in witches.

The possible functions within a community of this paradigm are manifold. It was in professional healers' interests to claim sources of power not usually accessible to the community, and claims of knowledge from fairies surely served this purpose, particularly for those who could not claim knowledge from books (cf. Purkiss 2000, 126-7; Thomas 1973, 727-8; Mathisen 1993). But fairy-lore could also be deployed in healing-practices themselves. Naming an illness, as by declaring someone to have been elf-schot or elf-grippit, was an important step in healing, since it implicitly brought the otherwise intangible illness within the scope of human knowledge, comprehension, and narratives (Alver and Selberg 1987, 23; compare Purkiss 2001). Metaphorical associations of schot "pain" with schot "projectile" may also have suggested other ways of concretising and healing the illness, but there is no evidence in our sources for these processes. In naming and in narratives, illnesses might be ascribed the ultimate source of fairies, situating their origins with a powerful group outside the community. This situation would again privilege healers, both because they claimed unique powers to protect the community from this outside force and because it mitigated their potentially marginal position by aligning their interests fundamentally with those of the in-group. The binary opposition between in-group and out-group established by fairy lore may also have been a force for social cohesion, the external threat encouraging the community's integrity and promoting solidarity with the victim, whose status within the community may otherwise have been compromised by illness.

Stein Maltman's detailed confessions support these readings. In the passage quoted, for example, Stein has all the healthy servants leave the house lest they "ressave skaith" from the patient. This is admittedly not the kind of community involvement which we might see in the collective bedside vigil. It suggests a liminal status for the patient, 
ensures that Stein's healing rituals directly affect the whole household, and emphasises that not only Jonet, but all its members are at risk from the supernatural forces which Stein counteracts. The same harm could have come to any of them. One might also speculate that the servants' subsequent return into the house established a clear closure to the liminal period, and a new and positive beginning for the community's attitude to Jonet.

Narratives of meetings with fairies in more detailed Scottish accounts have been interpreted to reflect dangers, social rules and social boundaries, and in their turn to have helped to encode and construct them (besides the studies already cited, see Miller 2002, 102-3). The linguistic evidence examined here does not contribute to these analyses, but it offers an important alternative perspective: whereas our Scottish narratives tend to focus on positive outcomes of transgression, such as the gaining of prophetic or healing powers, the linguistic evidence considered here emphasises its counterpart, the threat of illness. The threats by which fairies were thought to maintain their boundaries are what made transgression risky, and so made its rewards the more powerful; despite the prominence of fairies' rewards in our narrative material, the threats encoded in the linguistic evidence were presumably the more prominent of the pairing in early modern Scottish world-views.

\section{Elf-arrow-heidis and witchcraft}

The remaining trials present women accused of, or confessing to, schuting their victims. Neither form of elf-schot occurs, but in each case, the records specify that witches shot with elf-arrow-heidis, elf-arrow-stones, elf-stones or elf-arrows; these terms all seem to have denoted neolithic arrow-heads or similar stones. At a lexical level, then, these generally attest to a tradition of elvis harming people with projectiles (physical or metaphysical) only insofar as the terms presuppose such a tradition - which, as I have argued above, they need not. Nonetheless, the trials illuminate not only the relationships between fairies and witches, but how they changed during the period of the witch hunts. The earliest is that of Katherene Ross (Ross and Cromarty, 1590). Perhaps twenty-two of Katherene's alleged accomplices were also tried, mainly in 1577 (for a list see Katherene's entry in the SSW), but we have details about their actions only insofar as they are mentioned in Katherene's trial records. On this basis, the SSW marked Christiane Roiss (Ross and Cromarty, 1577) and Marion Neyne McAlester (Ross and Cromarty, 1590) for "elfshot," but only Katherene's trial offers evidence.

Katherene was noblewoman who tried to use witchcraft and poisoning to murder members of her family for political and financial reasons (see Maxwell-Stuart 2001, 135-41); although she was tried in 1590, most of the events were alleged to have taken place in 1577, which suggests this earlier date for the use of the terms under discussion. Katherene was accused of buying elf-arrow-heidis on several occasions and of "shooting" them at images of her intended victims (Pitcairn 1833, vol. 1, 192-3, 195, 198-9). The first account in her indictment is sufficient to show the method and terminology:

Thow art accusit, for the making of twa pictouris of clay ... the ane, maid for the distructioune and consumptioune of the young Laird of Fowlis, and the vthir for the young Ladie Balnagoune ... 
Quhilkis twa pictouris, being sett on the north syd of the chalmer, the said Loskie Loncart tuik twa elf arrow heides and delyuerit ane to ye (you) Katherene, and the vther, the said Cristian Rois Malcumsone held in her awin hand; and thow schott twa schottis with the said arrow heid, att the said Lady Balnagowne, and Loskie Loncart schott thrie schottis at the said young Laird of Fowlis.

[You are accused of making two figures from clay ... the one, made for the destruction and wastingaway of the young Laird of Fowlis, and the other for the young Lady Balnagowne ... These two figures being placed on the north side of the chamber, the aforementioned Loskie Loncart took two elf-arrow-heidis and handed one to you, Katherene, and the other the aforementioned Christiane Roiss Malcumsone held in her own hand; and you schott two schottis with the said arrow-head at the aforementioned Lady Balnagowne, and Loskie Loncart schott three schottis at the aforementioned young Laird of Fowlis.] (Pitcairn 1833, vol. 1, 192).

This account shows the internationally widespread technique of harming models of a victim in order to harm his or her person, and in this it is entirely conventional (for other British examples see Hole 1973). As in Meriorie Mutche's trial, this text may play on the polysemy of schot: when Katherene "schott twa schottis with the said arrow heid," did she "throw two throws," or "inflict two sharp pains"? Unfortunately, it is hard to be sure if this ambguity was intended. Katherene seems to have considered that elvis could assist her in her witchcraft, since at midsummer in 1576, she allegedly met with her accomplice Marion, who said that Katherene "wald gang in Hillis to speik the elf folk" ("should go into hills to speak to the elf-folk"; Pitcairn 1833, vol. 1, 196). Neither the purpose nor the consequence of this advice is recorded, though if Katherene were seeking elf-arrowheidis there, it would be broadly consistent with the statement of James VI in his Daemonologie that "sundrie Witches haue gone to death with that confession, that they haue ben transported with the Phairie to such a hill, which opening, they went in, and there saw a faire Queen, who being now lighter [having given birth], gaue them a stone that had sundrie vertues" (Craigie 1982, 51). However, there is nothing to suggest that elvis were involved in Katherene's witchcraft beyond having something undefined to do with the arrowheads.

The other three cases, from 1659-62, fall around the great witch panic of 1661-2, around eighty years after Katherene's alleged efforts with elf-arrow-heidis. They envisage more direct attacks by the witches and more obvious physical consequences, and although the data is too limited for certainty, this hints at changes in witchcraft-and fairy-beliefs since Katherene's time. The testimony of Isobel Thomsone against Jenet Miller is the earliest: [6]

when the said Isobell ... was reproveing her for beareing ane bourden wpon the Lords day The said Jenet Miller sate downe upon her knees courseing And said that she should have A mends of her And thereafter when she was layeing wakeing with a paine in her Arme she perceaved her thombe shot through with that which they call ane elffe stone And the blood of her thumbe sprinkled a longe the bed And there looking to the floore she saw her standing upon it with ane other who is dead.

[when the aforementioned Isobel ... was rebuking her [Jenet] for bearing a burden on the Lord's day, the aforementioned Jenet Miller knelt down upon her knees cursing, and said that she would have some compensation from her [Isobel]. And thereafter, when she [Isobel] was lying awake with a pain in her arm, she perceived her thumb to be shot through with the thing which is called an elfstone, and the blood of her thumb sprang out along the bed. And looking from there to the floor she saw her [Jenet] standing upon it with another person, who is dead.] (MacDonald 1935, 169).

Here, Jenet was apparently envisaged to have appeared before her victim in the night, in 
the company of "ane other who is dead"; such a dead person could in the folklore attested by the Scottish witchcraft trials be associated with the elvis or fareis, as in the case of Thom Reid mentioned above (cf. Purkiss 2000, 102-4; Henderson and Cowan 2001, 1921, 60-1, and passim). We are invited to infer that Jenet then schot her elf-stone directly at Isobel, with the maleficent assistance of her otherworldly companion. It is evident from this that by 1659 , witches could be envisaged to use elf-arrow-heidis directly as projectiles. Jenet's companion is also interesting: he may reflect the role in the Scottish trials of the fairy as a witch's familiar, whose similarities to the English animal familiars have recently been emphasised by Wilby (2000); comparison might also be made with the development of elben as familiars in German trials (cf. Edwards 1994, 21). It is tempting to infer that a tradition in which elvis caused ailments using projectiles (which may be implied in the Scotts' trials of 1650), has here been transferred to witches, with contact between healers and elvis now being developed to put elvis in the role of the familiar.

A few years later, when Jonet Morisone (Bute, 1662) gave her declarations in response to accusations of witchcraft, she claimed that others, including Margrat $\mathrm{N}^{\mathrm{i}}$ William, had schot their victims, envisaging the infliction of open wounds. Jonet said that "John Stephen ... was shott underneath the short ribbs and that quhen she found him there was a hole in it that ye might put your neive [fist] in" (MacPhail 1914-34, vol. 3, 24). Jonet's testimony does not mention fairies, but in Margrat's own trial (Bute, 1662), where several further transitive uses of schute occur, Margrat confessed that, as she was falling into poverty after the death of her livestock, she was approached by the Devil. He seems to have promised her wealth, but

he sought her sone [son] William a child of 7 yeires old which she promised to him and he gave her ane elf errow stone to shott [shoot] him which she did ten dayes therafter that the child dyed immediately therafter which grieved her most of anything that ever she did (MacPhail 1914-34, vol. 3, 18-9).

This account of William's death, then, not only includes the transitive use of schute, but the claim that the schuting was done with an elf-arrow-stone. Moreover, whereas the trials of Katherene Ross and Jenet Miller hint that fairies might have supplied the elfarrow-heid, this confession explicitly has the elf-arrow-heid come from the Devil. These points hint that the appearance of the Devil in Margrat $\mathrm{N}^{\circ}$ william's trial shows in part the recasting of fairies not only as familiars, but as the Devil himself (cf. Macdonald 2002, 46-8; Henderson and Cowan 2001, 125-36). The functional comparisons between the fairies and the Devil can be pressed. Margrat admitted the influence of the Devil concomitantly with expressions of guilt, repentance and extenuating circumstances: he provided Margrat with a suitably nefarious external origin for her confessed misdeeds, as fairies had provided Bessie Dunlop and Stein Maltman with suitably prestigious external origins for their methods and powers of healing.

These suggestions are supported by the famous sequence of four confessions by Issobell Gowdie (Nairn, 1662). Issobel "interspersed fairy and diabolical beliefs in her confessions ... to a degree that is unrivalled in any other known witch trial" (Henderson and Cowan 2001, 134). Although she confessed without any "compulsitouris" ("judicial torture"; Pitcairn 1833, vol. 3, 603), it is not clear what other processes of coercion or suggestion she might have undergone (cf. Levack 2002, 173-7; MacDonald 2002, 123 42). Even so, parts of her confessions are too unusual for us to doubt that they derived from Issobel rather than from her interrogators, and her accounts of fairies are twice cut off in the records with a curt "\&c.," implying that at least some of Issobel's confessions 
were not of interest to her prosecutors, and are not words put into her mouth (cf. Henderson and Cowan 2001, 4). Here it will suffice to discuss only Issobel's directly relevant statements. In her second confession, Issobel explained (the ellipses being Pitcairn's, marking manuscript lacunae, and words in sqare brackets his conjectural additions):

As for Elf-arrow-heidis, the Divell shapes them with his awin hand, [and syne deliueris thame] to Elf-boyes, who whyttis and dightis them with a sharp thing lyk a paking neidle; bot [quhan I wes in Elf-land ?] I saw them whytting and dighting them. Quhan I wes in the Elfes howssis, they will haw werie ........ them whytting and dighting; and THE Divell giwes them to ws, each of ws so many, quhen ........ Thes that dightis thaim ar litle ones, hollow, and boss-baked! They speak gowstie lyk. Quhen the Divell gives them to ws, he sayes,

'Sноот thes in my name, And they sall not goe heall hame!'

And quhan ve shoot these arrowes (we say) -

'I sноOт yon man in THE DivelLis name, He sall not win heall hame!

And this salbe alswa trw;

Thair sall not be an bitt of him on lieiw!'

We haw no bow to shoot with, but spang them from the naillis of our thowmbes. Som tymes we will misse; bot if thay twitch, be it beast, or man, or woman, it will kill, tho' they haid an jack wpon them.

[As for elf-arrow-heidis, the Devil shapes them with his own hand, [and thereafter delivers them] to elf-boys, who shape them and finish them off with a sharp thing like a packing needle (a needle for binding bundles); but [?when I was in Elf-land] I saw them shaping and finishing them. When I was in the elvis' houses, they will have very . ....... them shaping and finishing them; and the Devil gives them to us, to each of us this many, when ........ Those who finish them off are little ones, hollow and their backs concave [7]! They speak gruesomely.

When the Devil gives them to us, he says,

'Shoot this in my name, And they shall not go home hale!'

And when we shoot these arrows [we say]:

'I shoot that man in the Devil's name,

He shall not get home hale!

And this shall be also true,

There shall not be a bit of him alive!

We have no bow to shoot with, but flick them from the nails of our thumbs. Sometimes we miss, but if they touch, whether beast, man or woman, it will kill, even if they have a (protective) jerkin on.] (Pitcairn 1833, vol. 3, 606-7).

Issobel's fourth confession includes a similar passage (Pitcairn 1833, vol. 3, 615). The similarities may be due to scribal reference to the earlier confession or to Issobel herself echoing her previous account, which could have been well-established and somewhat formulaic. These confessions exhibit similar motifs to Margrat N'Williams's, but emphasise how well-developed the association of elf-arrow-heidis, shooting and the Devil could become, at least at the peak of witch-hunting in Scotland. This is not to say that Issobel was entirely innovative: the famous Old English charm Wið ferstice associates the infliction of a gescot (the etymon of schot) —which, the text implies, may be caused by ylfe (the etymon of elvis) — with projectiles and an image of smiths making 
weapons (Grattan and Singer 1952, 173-6). It could be that much of Issobel's confession is in the same tradition. The Old English text, however, neither mentions the Devil, nor obviously suggests that the harm is caused by members of the community like Issobel.

\section{Conclusions}

In all, I have accepted ten printed trials to pertain meaningfully to elf-shot in some sense. This is not a large number, cautioning against over-stating the significance of elf-shot traditions in early modern Scotland, though the point is somewhat mitigated by their wide distribution-Ross and Cromarty in the North, Bute in the South-West and Edinburgh in the South-East. Despite the small sample, some patterns are apparent. It emerges that compounds of elf with words for ailments - such as elf-schot (noun and participle) and elf-grippit - occur in or imply narratives about members of human communities healing harm probably thought to be done by fairies. By contrast, four of the five trials mentioning elf-arrow-heidis concern their use by human witches in maleficium. If in future editions, the SSW maintains its present definition of "elfshot," it is the latter group which should be included in the survey (possibly along with certain associated trials, such as Christiane Roiss, Ross and Cromarty, 1577; Marion Neyne McAlester, Ross and Cromarty, 1590; Jonet Morisone, Bute 1662; and Jonet Braidheid, Nairn 1662) — though in this case, changing the field name to elf-arrow-head would both remove ambiguity and be more in keeping with the language of the sources.

The differences in vocabulary in the trials reflect differences in their narratives. I have interpreted material from as early as 1576 to suggest a system in which healers acted from within the community against illness caused by an external, more powerful group, the fairies. Meanwhile, the use of elf-arrow-heidis in witches' maleficium, and maybe the idea that the elf-arrow-heidis might be supplied by fairies, is attested from 1590 (with reference to 1576-7). These two systems for the aetiology of illness - fairies and witches - must have co-existed for centuries, and certainly did so throughout the witchcraft trials. But the evidence hints that over time, fairy-beliefs were incorporated into witchcraft-beliefs. Already in the 1570s, Katherene Ross arguably tried to gain the power to harm by visiting the elf-folk, as healers in her society claimed that they had gained their powers to heal; but the more lurid accounts from 1659-62, which claim witches' direct shooting of elf-arrow-heidis, and imply or state their supply by familiars or the Devil, invite interpretation as innovations. They reorientate the construction of supernatural disease from deriving primarily from outside the community to deriving primarily from within: fairies, it can be argued, which in older belief-systems were an independent, external threat, became in these trials an adjunct of witches.

Explaining why these changes took place is beyond the scope of this paper. No doubt they arose in response to various pressures such as witch-panics and pressure from Church reformers to abandon or demonise both fairy-beliefs and their concomitant healing-beliefs (cf. Henderson and Cowan 2001, 106-41). But any explanation would demand a dynamic process of interaction between diverse groups of tradition-participants in early modern Scotland, in which beliefs positing forces external to society as sources of supernatural harm were progressively assimilated into beliefs positing sources of supernatural harm from within society. However, in offering new evidence for the alternatives to witchcraft among the sources of supernatural harm recognised in early 
modern Scotland, the evidence considered here also serves to emphasise that the trials may hide important paradigms for explaining and healing harm in the societies which experienced the witchcraft trials (cf. Hutton 2002, 20, 27-32). Unsurprisingly, fairies only appear as an aetiology of illness in the witchcraft trials when the trial of a healer happens to mention them, or when they abet witches. I have suggested a paradigm in which the sources of supernatural harm were fairies whose harm could be healed but whose threats could not be neutralised at source - fairies could not be brought to trial. This paradigm privileged the healer over judicial machinery. This point not only provides another reason why healers might have identified fairies as the source of ailments instead of witches, but suggests that when communities needed to neutralise rather than merely avert supernatural threats, they were more likely to identify witches as the source of illness than fairies. This, then, may have been another important factor in the rise and development of witchcraft trials and their associated beliefs.

By paying close attention to the language of our texts, then, we can revise old assumptions about the character of Scottish beliefs at the time of the witchcraft trials. By situating this linguistic evidence in its narrative contexts, and adducing appropriate interpretative models, we can tell stories about Scottish fairy-belief quite different from those which dominate the narrative sources. These provide convincing, if only occasional, alternative perspectives on the culture in which the Scottish witchcraft trials took place. The trial-evidence systematically de-emphasises the place of fairies in the aetiology of illness, and their functions in society - and there are hints that the trials themselves may have altered communal attitudes to the role of fairies, at least temporarily. These approaches demand further investigation and substantiation, not only from more extensive examination of the Scottish witchcraft trials, but also from the reanalysis of later Scottish evidence and earlier English evidence, or by comparison with other North European material, such as the role of Elben in the German witchcraft trials. Such research is now increasingly viable on account of the new research tools available for Scottish history. [8]

\section{Notes}

[1] For DOST see $<$ http://www.dsl.ac.uk/dsl/index.html>. For the Helsinki corpus see the International Computer Archive of Modern and Medieval English website at $<$ http://helmer.hit.uib.no/icame.html $>$ or the Oxford Text Archive at $<$ http://ota.ahds.ac.uk/>. For the SSW, $<\mathrm{http}$ ://www.arts.ed.ac.uk/witches/index.html $>$. The quotation is from the "Survey of Scottish Witchcraft Database Documentation and Description" to be downloaded with the database, p. 55.

[2] "Survey of Scottish Witchcraft Database Documentation and Description," pp. 33, 36.

[3] "Survey of Scottish Witchcraft Database Documentation and Description," p. 32.

[4] For some further examples (not exhaustive), see DOST sub Schute §25c; Gillon 1953, vol. 1, 109 (Isobel Young, Haddington, 1629); vol. 1, 137 (Katharine Oswald, Edinburgh, 1629); vol. 1, 211 (Alisone Nisbet, Berwick, 1632), cited by Henderson and Cowan 2001, 77, 101; Smith 1974, vol. 3, 599 (Johnne Brughe, Kinross, 1643), marked for "elfshot" by the SSW. 
[5] The SSW notes that "I am sure this is the same as Steven Maltman from Leckie who was investigated for charming and healing by the presbytery in 1628"; oddly, it does not mark this trial for elfshot. I have only seen the printed account of Stein's trial, partly paraphrased, published by one R. M. F. (1893-1908).

[6] This seems surely to be SSW Jonet Miller, Linlithgow, 1661, but the SSW entry seems to be based only on her trial in Edinburgh, and does not mark the trial for "elf-shot". MacDonald found his material upside down at the end of a volume of Kirkliston session records, so it may have been overlooked by the SSW.

[7] "Boss-baked" has often been understood as "hunch-backed" (e.g. Henderson and Cowan 2001, 55), but DOST gives "hollow-backed" (cf. DOST, sub Bosba(c)ked): bos seems to have denoted both convex and concave forms. DOST may be paralleled by modern Scandinavian otherworldly beings who have hollow backs like rotten logs (e.g. Erixon 1961, 34).

[8] An earlier version of this paper was presented in the Scottish Medieval Studies Seminar series at the University of Glasgow, at which I received much helpful advice. I am further indebted to friends who have commented on it: Bethany Fox, Katie Lowe, Graham Caie, Matti Kilpiö, Leena Kahlas-Tarkka and Folklore's readers; and to Dave Cochrane, Rory Naismith and Charles West for sending me research materials across the North Sea.

\section{References Cited}

Alver, Bente Gullveig and Torunn Selberg. "Folk Medicine as Part of a Larger Concept Complex." Arv 43 (1987):21-44.

Bonser, Wilfrid. The Medical Background of Anglo-Saxon England: A Study in History, Psychology and Folklore. The Wellcome Historical Medical Library, New Series 3. London: Wellcome Historical Medical Library, 1963.

Carr, Charles T. Nominal Compounds in Germanic. St Andrews University Publications 41. London: Oxford University Press, 1939.

Cockayne, Oswald, ed. Leechdoms, Wortcunning and Starcraft of Early England. 3 vols. The Rolls Series 35. London: Longman, 1864-6.

Craigie, James, ed. Minor Prose Works of King James VI and I: Daemonologie, The Trve Lawe of Free Monarchies, a Counterblaste to Tobacco, a Declaration of Sports. Scottish Text Society, $4^{\text {th }}$ Series 14. Edinburgh: The Scottish Text Society, 1982.

Craigie, W. A., ed. The Maitland Folio Manuscript: Containing Poems by Sir Richard Maitland, Dunbar, Douglas, Henryson, and Others. 2 vols. The Scottish Text Society, Second Series 7, 20. Edinburgh: The Scottish Text Society, 1919-27.

Edwards, Cyril. "Heinrich von Morungen and the Fairy-Mistress Theme." In Celtic and Germanic Themes in European Literature, ed. Neil Thomas. 13-30. Lewiston, N. Y.: Mellen, 1994.

Erixon, Sigurd. "Some Examples of Popular Conceptions of Sprites and other Elementals in Sweden during the $19^{\text {th }}$ Century." In The Supernatural Owners of Nature: Nordic Symposion on the Religious Conceptions of Ruling Spirits (genii locii, genii speciei) and Allied Concepts, ed. Åke Hultkrantz. Acta Universitatis Stockholmiensis, Stockholm Studies in Comparative Religion, 1. 34-37 Stockholm: Almqvist \& Wiksell, 1961.

F., R. M.. "The Witch Doctor of Leckie.” In The Stirling Antiquary: Reprinted from "The Stirling Sentinel”, ed. W. B. Cook. Vol. 4, 185-91. 4 vols. Stirling: Cook and Wylie, 
1893-1908.

Fox, Denton and William A. Ringler, eds. The Bannatyne Manuscript: National Library of Scotland Advocates’ MS. 1.1.6. London: Scolar Press, 1980.

Fraser, William, ed.. Memoirs of the Maxwells of Pollok. 2 vols. Edinburgh: [n. pub.], 1863.

Gillon, Stair A., ed. Selected Justiciary Cases 1624-1650, vol. I. The Stair Society 16. Edinburgh: The Stair Society, 1953.

Gilmore, John, "Witchcraft and the Church in Scotland Subsequent to the Reformation." Unpublished Ph.D. thesis, University of Glasgow, 1948.

Goodare, Julian, ed. The Scottish Witch-Hunt in Context. Manchester: Manchester University Press, 2002.

Grattan, J. H. C. and Charles Singer, eds. Anglo-Saxon Magic and Medicine. Publications of the Wellcome Historical Medical Museum, New Series 3. London: Oxford University Press, 1952.

Grienberger, Theodor von. "Der Münchener Nachtsegen.” Zeitschrift für Deutsches Altertum und Deutsche Litteratur 41 (1897):335-63.

Hall, Alaric. "Calling the Shots: The Old English Remedy Gif hors ofscoten sie and AngloSaxon Elf-Shot." Forthcoming for Neuphilologische Mitteilungen.

Henderson, Lizanne, and Edward J. Cowan. Scottish Fairy Belief: A History. East Linton: Tuckwell, 2001.

Hole, Christina. "Some Instances of Image-Magic in Great Britain." In The Witch Figure: Folklore Essays by a Group of Scholars in England Honouring the $75^{\text {th }}$ Birthday of Katharine M. Briggs, ed. Venetia Newall. 80-94. London: Routledge \& Kegan Paul, 1973.

Honko, Lauri. Krankheitsprojektile: Untersuchung über eine urtümliche Krankheitserklärung. FF Communications 178. Helsinki: Suomalainen tiedeakatemia, 1959.

Horstmann, Carl, ed. The Early South-English Legendary or Lives of Saints I: MS. Laud, 108, in the Bodleian Library. Early English Text Society 87. London: Trübner, 1887. Hutton, Ronald.

"The Global Context of the Scottish Witch-Hunt." In Goodare 2002, 16-32. Jolly, Karen Louise. Popular Religion in Late Saxon England: Elf-Charms in Context. Chapel Hill, N.C.: University of North Carolina Press, 1996. Levack, Brian P. "The Decline and End of Scottish Witch-Hunting.” In Goodare 2002, 166-

81. Lexer, Matthias. Mittelhochdeutsches Handwörterbuch. Leipzig: Hirzel, 1869-76.

MacDonald, Angus. "Witchcraft in Kirkliston in the Seventeenth Century." The Scots Law Times: News (20 July 1935):169.

MacDonald, Stuart. The Witches of Fife: Witch-Hunting in a Scottish Shire, 1560-1710 (East Linton: Tuckwell, 2002).

MacPhail, J. R. N., ed. Highland Papers. 4 vols. Publications of the Scottish History Society, Second Series 5, 12, 20, 22. Edinburgh: Scottish History Society, 1914-34.

Marchand, Hans. The Categories and Types of Present-Day English Word-Formation: A Synchronic-Diachronic Approach. $2^{\text {nd }}$ edn. Munich: Beck, 1969.

Mathisen, Stein R. "North Norwegian Folk Legends about the Secret Knowledge of the Magic Experts." Arv 49 (1993):19-27.

Maxwell-Stuart, P. G., Satan's Conspiracy: Magic and Witchcraft in Sixteenth-Century Scotland (East Linton: Tuckwell, 2001).

Miller, Joyce. "Devices and Directions: Folk Healing Aspects of Witchcraft Practice in Seventeenth-Century Scotland.” In Goodare 2002, 90-105.

Normand, Lawrence and Gareth Roberts, eds. Witchcraft in Early Modern Scotland: James VI's "Demonology" and the North Berwick Witch Trials. Exeter: University of Exeter Press, 
2000.

Pitcairn, Robert, Ancient Criminal Trials in Scotland. 3 vols. Bannatyne Club 42. London and Edinburgh: The Maitland Club, 1833.

Purkiss, Diane. Troublesome Things: A History of Fairies and Fairy Stories. London: Allen Lane, 2000.

Purkiss, Diane. "Sounds of Silence: Fairies and Incest in Scottish Witchcraft Stories." In Languages of Witchcraft: Narrative, Ideology and Meaning in Early Modern Culture, ed. Stuart Clark. 81-98. Basingstoke: Macmillan, 2001.

Smith, J. Irvine, ed. Selected Justiciary Cases. Vols 2-3. The Stair Society 27-8. Edinburgh: The Stair Society, 1974.

Stuart, John, ed. The Miscellany of the Spalding Club. 5 vols. Spalding Club Publications 3, 6, 16, 20, 24. Aberdeen: Spalding Club, 1841-52.

Söderwall, K. F. Ordbok öfver svenska medeltids-språket. 2 vols. Lund: Svenska fornskriftsällskapet, 1884-1918.

Thomas, Keith. Religion and the Decline of Magic: Studies in Popular Beliefs in Sixteenthand Seventeenth-Century England. Harmondsworth: Penguin, 1973.

Wilby, Emma. "The Witch's Familiar and the Fairy in Early Modern England and Scotland." Folklore 111 (2000):283-305.

\section{Biographical Note}

Alaric Hall is completing a PhD at the University of Glasgow on the character and significance of beliefs in elves in medieval English-speaking cultures. He has also published on medieval British and Scandinavian texts, languages and traditions.

Further details will be found at $<$ http://www.alarichall.org.uk $>$. 